Porsiel, N., Hernández, S., Cordier, D., \& Heidemeyer, M. (2021). The devil is coming: Feeding behavior of juvenile Munk's devil rays (Mobula munkiana) in very shallow waters of Punta Descartes, Costa Rica. Revista de Biología Tropical, 69(Suppl. 2), S256-S266. https://doi. org/10.15517/rbt.v69iS2.48744

\title{
The devil is coming: Feeding behavior of juvenile Munk's devil rays (Mobula munkiana) in very shallow waters of Punta Descartes, Costa Rica
}

Nathalie Porsiel ${ }^{1}$; (D https://orcid.org/0000-0002-3030-8300

Sebastián Hernández ${ }^{2,3}$; (iD https://orcid.org/0000-0002-2908-6050

Damien Cordier ${ }^{4}$; (D https://orcid.org/0000-0002-4583-3212

Maike Heidemeyer*4,5; (D) https://orcid.org/0000-0001-7547-5631

1. University of Hamburg, Institute of Hydrobiology ad Fisheries Sciences, Hamburg, Germany; Nathalie.Porsiel@posteo.de

2. Sala de Colecciones Biológicas, Facultad de Ciencias del Mar, Universidad Católica del Norte, Antofagasta, Chile; pintarroja@gmail.com

3. Molecular Biology Lab, Center for International Programs, Universidad Veritas, San José, Costa Rica.

4. Asociación para la Conservación Integral de Recursos Naturales Equipo Tora Carey, El Jobo, La Cruz, Guanacaste, Costa Rica; tempatalkite@hotmail.ca

5. Centro de Investigación en Ciencias del Mar y Limnología (CIMAR), Universidad de Costa Rica, San José, Costa Rica; maike.heidemeyer@ucr.ac.cr (*Correspondence)

Received 30-I-2021. Corrected 28-IV-2021. Accepted 15-VI-2021.

\begin{abstract}
Introduction: Identifying critical habitats for vulnerable elasmobranch species is crucial for effective conservation measures. The Munk's devil ray (Mobula munkiana) is endemic to the Eastern Pacific, but yet little is known about its biology, ecology, and habitat use. As filter feeders, it is assumed that this species concentrates at high-productive upwelling regions, such as the Costa Rican Dome. Like many elasmobranchs, its populations are highly depleted and require urgent information to inform better conservation measures.

Objective: The study was conducted to gain information on a unique behavior observed in juvenile M. munki$a n a$, so further information can be provided on early life stages of this vulnerable species.

Methods: From June to September 2017 and in August 2018, the feeding behavior of juvenile Mobula munkiana was observed in two shallow bays located at Punta Descartes, North Pacific Costa Rica. Individuals were captured using a non-lethal method to obtain data on size, weight, and sex distribution. Plankton samples $(\mathrm{n}=$ 100) were taken at both bays throughout the months to infer diet composition.

Results: Munk's devil rays showed a repetitive swimming movement parallel to the beach, feeding exclusively in the shallow breaking zone of the low tide waves at depth $<50 \mathrm{~cm}$. A total of $12 \mathrm{M}$. munkiana (11 live and one found dead) indicated a juvenile feeding aggregation ranging from $490-610 \mathrm{~mm}$ in disk width and $1400-$ $2300 \mathrm{gr}$ in weight. The sex ratio (males to females) was 3:1. Zooplankton of the order Mysidacae was found in the highest abundance in the breaking zone.

Conclusions: The specific behavior and seasonal occurrence of juvenile Munk's devil rays in this area seem to be driven by prey abundance. More research is needed to conclude the presence of reproductive adults at deeper depths and the year-round habitat use of Punta Descartes. The area is threatened by unsustainable development and requires realistic management strategies to guarantee the survival of vulnerable species and their critical habitats.
\end{abstract}

Key words: Mobula munkiana; juvenile; Munk’s devil ray; migration; prey abundance; feeding. 
Mobulids are pelagic planktivorous and globally distributed in warm subtropical to tropical waters (Notarbartolo di Sciara et al., 2017). They belong to the single genus Mobula, that currently recognizes two manta (and a putative species in the Atlantic) and nine devil ray species (Hosegood et al., 2020; White et al., 2018). While manta rays are the largest rays (and among the largest fishes) in the world, devil or mobula rays are much smaller but resemble their larger sister species in both morphology and biology. For instance, all mobulids exhibit long-term gestation periods and low annual reproductive output, and are extremely long-lived (Couturier et al., 2012). However, while manta rays have been reported to undertake extensive migrations of several hundred kilometres both horizontally (Germanov \& Marshall, 2014) and vertically (Braun et al., 2015), little is known about the movement patterns of devil rays. A study of Croll et al., 2012 showed less vertical migration in a devil ray species. Tagged individuals of Mobula mobular (japanica) in the Eastern Tropical Pacific stayed close to the surface, while their primary prey shows diel migration of from more than 100 meters to the surface (higher depths at daytime to surface at night-time).

The occurrence of mobulids at distinct locations and/or habitats has been attributed to both an interplay of environmental conditions, such as productivity, temperature, and food availability (Lezama-Ochoa et al., 2019; Rohner et al., 2014) and biological requirements, like mating and availability of cleaning stations (Alves de Mendonça et al., 2020; Jaine et al. 2012). In the Eastern Pacific, the occurrence of devil rays is connected to higher oceanic productivity, such as the upwelling systems along the coast of Baja California Peninsula, Galapagos Islands, and Peru, and the oceanic upwellings of the Costa Rican Dome (Lezama-Ochoa et al., 2019). Different dietary studies from stomach contents and stable isotope analysis suggest that most mobulid species are predominantly planktivorous and, except for M. munkiana, overlap in their trophic preference of euphausiids as principal prey
(Notarbartolo di Sciara, 1988; Sampson et al., 2010; Stewart et al., 2017).

Mobula munkiana, also known as Munk's devil ray, attains the smallest size as mature adults in the genus Mobula (Notarbartolo di Sciara, 1987). This species is endemic to the Eastern Tropical Pacific, distributed from Baja California Peninsula, Mexico, to Peru, including the Galapagos Islands of Ecuador (Marshall et al., 2019). Like some of its sister species, M. munkiana is often observed in large schools composed of thousands of individuals, particularly when mysid (Mysidium sp.) and euphausiid (Nyctiphanes simplex) shrimps are most abundant (Notarbartolo di Sciara, 1988; Palacios et al., 2021). Similarly, their large aggregations have also been attributed to mating behaviors (Stewart et al., 2018). In the Gulf of California, Mexico, females are known to segregate from males upon reaching sexual maturity (López, 2009; Notarbartolo-di-Sciara, 1988), and a recent study suggests a further ontogenetic segregation of neonate, juvenile, and adult habitats (Palacios et al. 2021). Additionally, the last study found that juvenile residence was more related to warmer water temperatures than zooplankton abundance.

The northwest coast of Costa Rica is directly influenced by the oceanic upwelling system described as the Costa Rican Dome (Fernández-Álamo \& Färber-Lorda, 2006; Fiedler, 2002). Around Punta Descartes, the countries northernmost peninsula on its Pacific coast, this phenomenon is particularly evident during January - April, when sea temperatures reach as low as 15 degrees (Cortés et al., 2014). During this period, coastal productivity peaks and, in consequence, triggers high zooplankton abundance during most of the year (FernándezÁlamo \& Färber-Lorda, 2006; Fiedler 2002). Punta Descartes has been classified as an area of major conservation relevance because of its extremely high coastal-marine biodiversity and lack of protected areas (Alvarado et al., 2011). Nonetheless, to date, there is little information available on the abundance of ecologically important species, especially those that 
require enhanced conservation measures and that inhabit this area.

Mobula munkiana, like all species within this genus, have experienced severe population declines mainly due to overexploitation and bycatch (Couturier et al., 2012; Croll et al., 2016; Stewart et al., 2018) and is currently classified as vulnerable based on an assessment by IUCN (Marshall et al., 2019). In the Eastern Pacific of Costa Rica, by-catch mortalities are mainly associated to tuna purse-seine fisheries, often concentrated at the Costa Rican Dome (Croll et al. 2016; Lezema-Ochoa et al., 2019). Targeted fisheries of devil rays mainly occur in Mexico, Peru, and Ecuador, either for local and regional use and consumption of its meat or to supply the Asian medicinal market with its gill plates, where they are traded at high prices (Couturier et al., 2012; Croll et al., 2016; O’Malley et al., 2017). As a member state of relevant international treaties, such as the Convention on the Conservation of Migratory Species of Wild Animals (CMS), Convention on International Trade in Endangered Species of Wild Flora and Fauna (CITES), and the Inter-American Tropical Tuna Commission (IATTC), both manta and devil rays are protected under international and national law. Specifically, the national decree No. 38027-MAG currently prohibits any fishery, onboard retention, landing, or commercialization of mobulid rays.

Although M. munkiana has been listed in the Costa Rican elasmobranchs checklist (Espinoza et al., 2018), there are no current studies that specifically address the ecological requirements of this species in Costa Rican waters. Information addressing this species' biology, ecology, and population trends, to enhance effective conservation measures (Lawson et al., 2017; Marshall et al., 2019) is urgently needed. Here we report, for the first time, on the presence, size, and sex distribution, as well as feeding behavior of juvenile Munk's devil rays in northwest Costa Rica. We associate its presence in extremely shallow waters with the zonal distribution of Mysis sp. and detail a non-lethal sampling method for M. munkiana.

\section{MATERIALS AND METHODS}

Study sites: El Jobo $\left(11^{\circ} 02^{\prime} 01.5^{\prime \prime} \mathrm{N} \&\right.$ $85^{\circ} 44^{\prime} 05.4$ ' W) and Rajada (11 $011^{\prime} 48.2^{\prime \prime} \mathrm{N} \&$ $85^{\circ} 44^{\prime} 42.6$ " W) beaches are adjacent bays on the northernmost peninsula of Punta Descartes, in Guanacaste province, Northwest Costa Rica (Fig. 1). Their white sandy bottoms are fringed by rocky reefs and outcrops that shelter the bays during most of the year. Both bays are approximately one kilometre wide. Inside the bay, at the peak of the rainy season from June to September, devil rays are commonly observed in areas of shallow waves close to the beach, identified by their uniform dark-violet coloration and surfing fin tips when swimming close to the surface.

Description of feeding behavior: The swimming behavior of the devil rays was registered repeatedly by three observers (authors $\mathrm{NP}, \mathrm{DC}$, and $\mathrm{MH}$ ) in 13 days (nine at El Jobo and four at Rajada) between June and September of 2017 and 2018, respectively. Observations took place either from the beach and inside the water at variable distances between one to twenty meters. Videographic evidence was further collected with a drone at a height of approximately five meters (DJI Mavic Pro 1). We registered when the rays unfurled their cephalic lobes, as this behavior characterizes feeding activity in mobulids (Ari \& Correia, 2008; Mulvany \& Motta, 2013), as well as their movements in response to the movements of the waves.

Devil ray capture: We then used a ten meter long, $1.2 \mathrm{~m}$ high silk nylon minnow seine net (mesh size ca. one $\mathrm{cm}$ ), rolled up and sustained at each end respectively by one person, to block the rays' swimming direction behind the spilling wave break at a depth of approximately $1 \mathrm{~m}$. Once the rays were in close proximity, the net was unrolled on the deeper end to encircle the individual(s) and closed on both ends. The rays were maintained inside the net with sufficient swimming ability and were taken out one by one with a hand net 


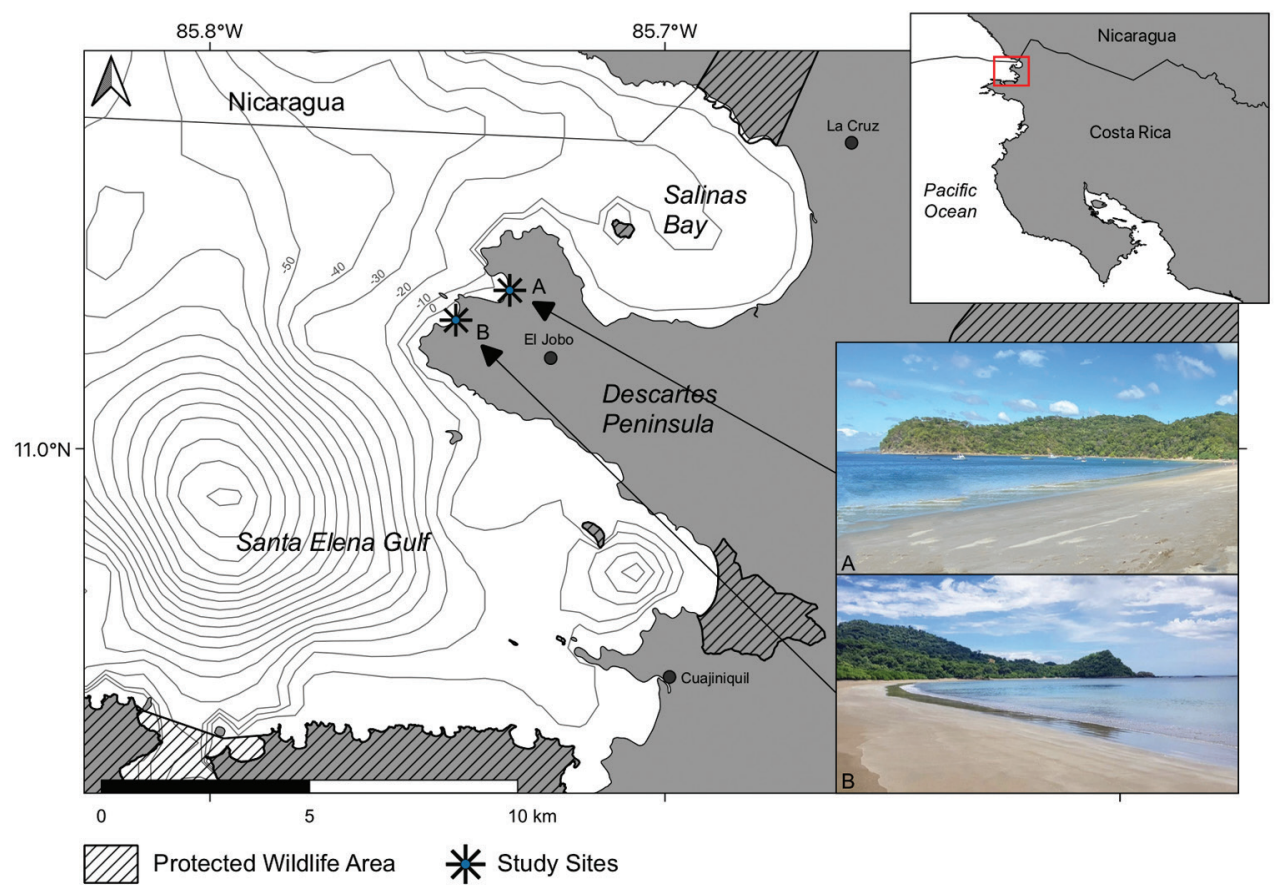

Fig. 1. Location of the two study sites on the Descartes Peninsula in northwest Costa Rica: A) El Jobo Beach, B) Rajada Beach. Bathymetry is indicated in meters below sea level.

for subsequent manipulation. We manipulated each ray on a floating platform (Fig. S1), and because devil rays require the water flow to breathe, data collection was undertaken in two to three sequential steps. Between those steps, the rays were moved inside the hand net in the water. For the entire procedure, a team of four to five people was required, and completing the protocol took about five minutes.

Data collection: Upon successful capture, individuals were measured, weighed, sexed, and tagged. All measurements were recorded with a flexible measuring tape $( \pm 0.5 \mathrm{~cm})$. The disc width $\left(\mathrm{W}_{\mathrm{D}}\right)$ was recorded from fin tip to fin tip, total length $\left(T_{L}\right)$ from the center of the superior mouth opening to the tip of the tail, and the tail length (TaL) from the base of the tail to the tip. Weight was taken with an electronic hanging scale (model H.S., brand UWE, manufactured in Taiwan) with a capacity of 15 $\mathrm{kg} \pm 0.01 \mathrm{~kg}$. The rays were tagged with $3 \mathrm{~cm}$ long T-bar anchor tags (model FD-94, Floytag,
Seattle, USA) on the right anterior side of the tail base. We also included one fresh individual found dead on the 30th of June 2017, on Rajada beach, in which stomach content was inspected. Males and females were identified according to the presence or absence of claspers. Size at sexual maturity for this species (López, 2009; Notarbartolo di Sciara, 1988) was used to infer the life history stage. Thus, males with $\mathrm{W}_{\mathrm{D}}<870 \mathrm{~mm}$ (Notarbartolo di Sciara, 1988) and females with $\mathrm{W}_{\mathrm{D}}<970 \mathrm{~mm}$ (López, 2009), respectively, were classified as juveniles.

Zooplankton surveys: Because of the overwhelming abundance of mysid shrimps found in the stomach contents of one dead devil ray, our surveys focused exclusively on identifying the abundance of crustacean zooplankton at different depths. On five occasions between July and September 2017, plankton surveys were conducted at El Jobo and Rajada beach. Samples were collected with a $12.7 \mathrm{~cm}$ mouth diameter plankton net $(153 \mu \mathrm{m}$ nylon 
cloth, 10 mesh; brand LaMotte, manufactured in UK) and a $50 \mathrm{ml}$ tube attached at the cod end of the net. Samples were taken in the breaking zone (BZ) of the waves at a depth of $0.5 \mathrm{~m}$ and the shoaling zone (SZ) of $2.5 \mathrm{~m}$ depth, respectively, from the surface and the bottom, where the net was dragged for 10 seconds. On every sampling day, five plankton tows per zone (BZ \& SZ from surface and bottom) were taken ( N $=100)$. Samples were inspected under a microscope (10x magnification), morphologically identified, and individuals counted.

Statistical analysis: Differences between sexes were evaluated for all morphometric measurements using conventional t-Student tests, and the linear relationship of weight and disk width was assessed with Pearson's correlation coefficient. Samples taken at Rajada and El Jobo were grouped into surface, and bottom plankton samples, respectively, from BZ and $\mathrm{ZZ}$, and differences in the number of individuals counted between zones (BZ/SZ) and depths (surface/bottom) were assessed using a 2-factor ANOVA with replications (El Jobo and Rajada beaches). All analyses were conducted at a significance level of $\mathrm{P}=0.05$, using the program $\mathrm{R}$ (R Core Team, 2020).

\section{RESULTS}

Feeding behavior: Devil rays were observed following the breaking waves along the shallow slopes of El Jobo and Rajada beaches (Fig. 1A, Fig. 1B). This behavior was especially conspicuous during low tide and is generalized as followed (Fig. 2A): Single rays or small groups of $2-10$ individuals swim parallel to the beach in both directions directly in the surf zone, behind the breaking waves. They swim in slow to moderate speed close to the surface often with their pectoral fin tips cutting through the surface of the water. Upon the surging of a wave, they abruptly turn towards the beach and follow the wave by rapidly flapping their pectoral fins and notably increasing

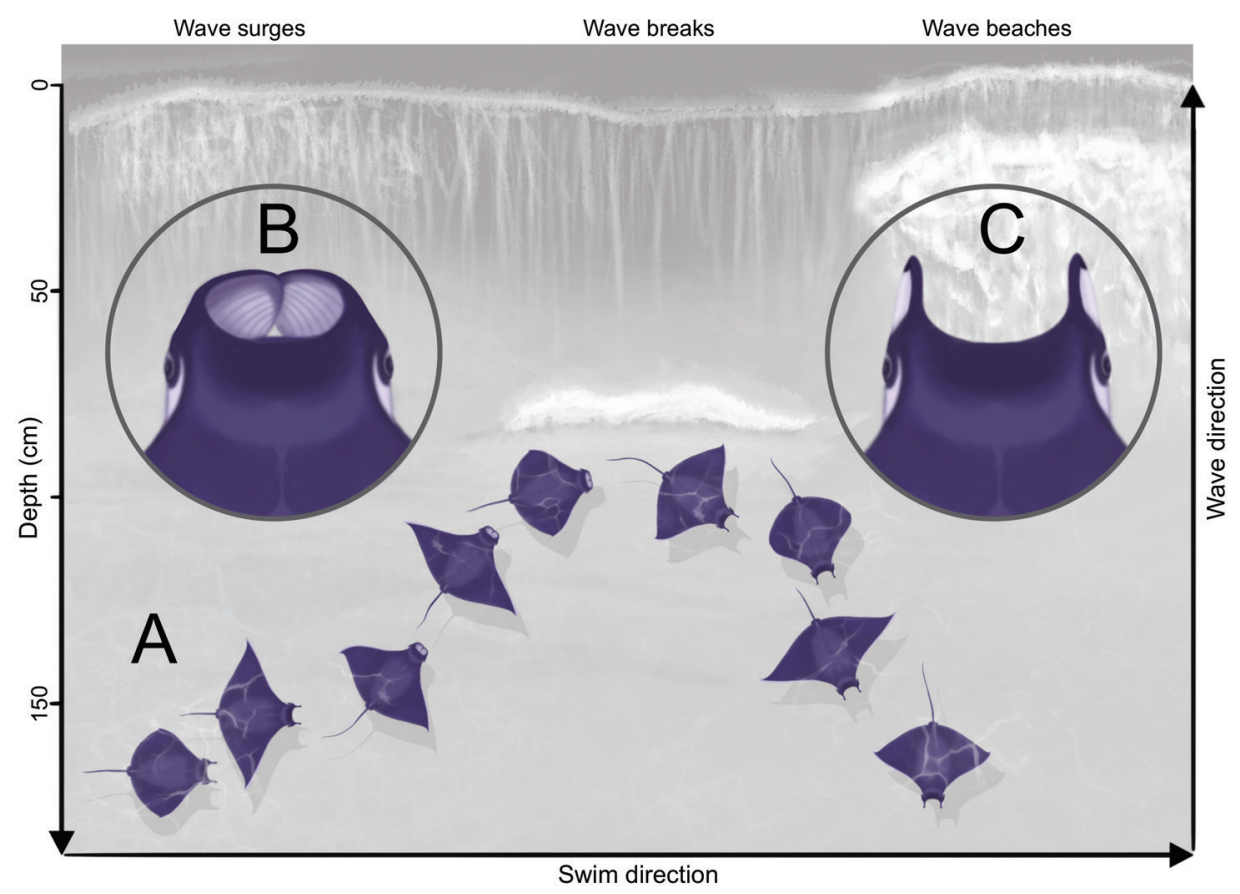

Fig. 2. A) Illustration of the generalized swimming behavior of devil rays at shallow depths in response to the movement of waves at El Jobo and Rajada beaches; B) Close up of unfurled cephalic lobes during the shoaling of the wave, and C) furled cephalic lobes during non-feeding behavior (see text). 
speed while following the maximum amplitude of the shoaling wave. Some individuals additionally conduct circular up and down movements. Depending on the depth at which a wave breaks, some individuals enter waters as shallow as $20 \mathrm{~cm}$. Just before the wave break, they abruptly turn around at a sharp angle and continue swimming at a slower pace into deeper waters. Individuals unfurl their cephalic lobes the moment they start following the shoaling wave and move towards the beach (Fig. 2B), which were clearly observed as round white patches from above the water. Immediately after they redirect back to deeper waters, these cephalic lobes are furled back to their cephalic horns (Fig. 2C).

Devil ray sampling: In a total of 9 surveys carried out between June and September of $2017(\mathrm{~N}=8)$ and $2018(\mathrm{~N}=1), 11$ M. munkiana were captured at El Jobo beach, with no successful capture at Rajada. Including the dead individual from Rajada, our data set contained 12 individuals, nine $(75 \%)$ were identified as males and three (25\%) as females, with a male to female sex ratio of $3: 1$. Because there was no difference $(p>0.2)$ in WD nor weight, males and females were pooled for further analysis. WD ranged from 490 to $610 \mathrm{~mm}$ $(545 \pm 35 \mathrm{~mm}$, mean $\pm \mathrm{SE})$ and weight from 1400 to $3100 \mathrm{~g}(2108 \pm 434 \mathrm{~g}$, mean $\pm \mathrm{SE})$, which were highly correlated $(\mathrm{r}(11)=0.93, \mathrm{P}<$ 0.000; Fig. 3). TL ranged from 460 to $840 \mathrm{~mm}$ $(572 \pm 98 \mathrm{~mm})$, and TaL from 150 to $445 \mathrm{~mm}$ (386 $\pm 80 \mathrm{~mm})$. All individuals were classified as juveniles.

Zonal distribution of mysids: The number of individual mysids differed significantly among zones and depths $(\mathrm{F}(3,39)=66.73, \mathrm{P}<$ $0.0001)$, with the highest abundance of crustaceans of the order Mysidacae registered at the bottom of the BZ followed by the surface of the BZ (Fig. 4). There was no significant difference among sites nor dates $(\mathrm{P}>0.1)$.

\section{DISCUSSION}

This is the first study that characterizes the size distribution, sex ratio, and feeding behavior of juvenile M. munkiana in Costa Rica and Central America. Our findings suggest that Punta Descartes serves as a juvenile feeding ground for this vulnerable species during several months of the year. With a mean $\mathrm{W}_{\mathrm{D}}$ of $545 \pm$ $35 \mathrm{~mm}$, our sample resembles the average $W_{D}$ of neonates at the recently described nursing ground at Ensenada Grande, Baja California Peninsula, suggested as such by the presence of the umbilical scar (Palacios et al., 2021). Although we did not intentionally register this

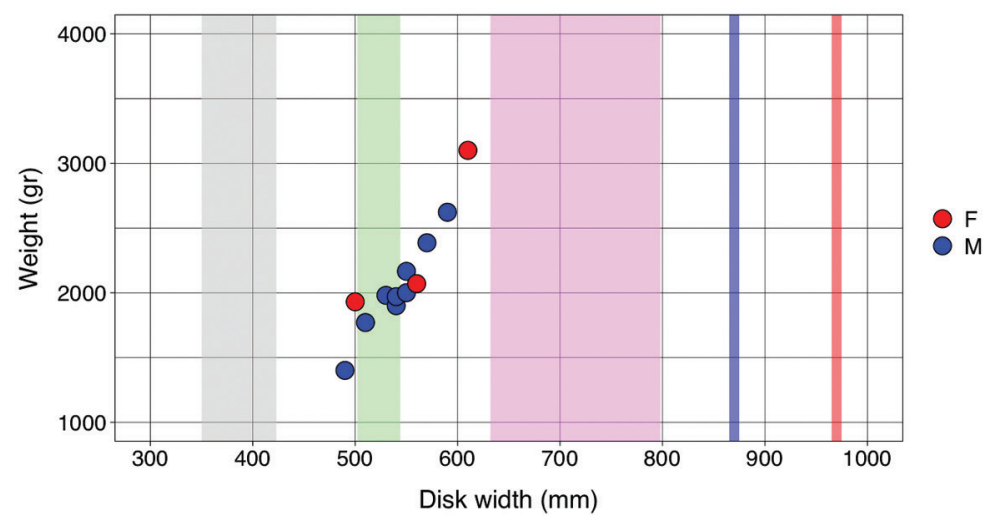

Fig. 3. Linear relationship of female (in red) and male (in blue) Mobula munkiana $(\mathrm{N}=12)$ disk width $\left(\mathrm{W}_{\mathrm{D}}\right.$; mm) and weight (g) sampled in Punta Descartes, North Pacific Costa Rica. For reference, $W_{D}$ of estimated size at birth range (Broadhurst et al. 2019; Notarbartolo di Sciara, 1988) is indicated in grey, mean \pm SD of neonates and juveniles in green and violet, respectively (Palacios et al. 2021), and male and female maturity sizes, respectively in blue and red (Notarbartolo di Sciara, 1988). 


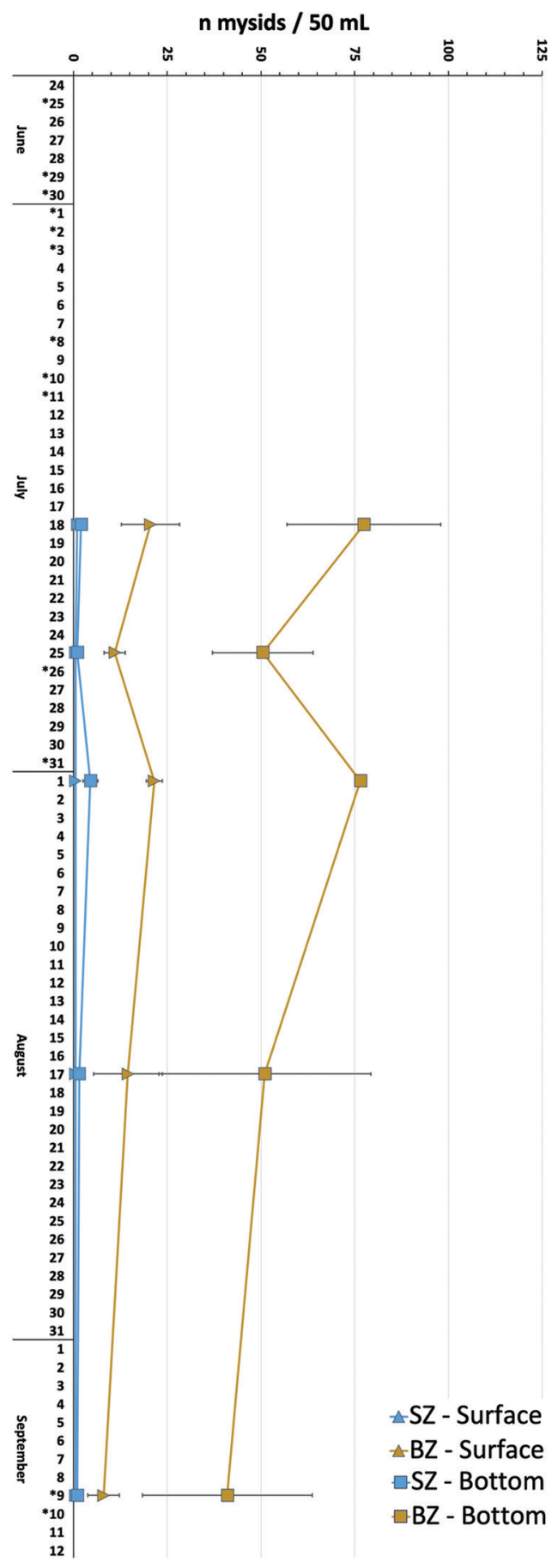

Fig. 4. Mean $( \pm \mathrm{SD})$ distribution (n individuals / $50 \mathrm{ml}$ ) of mysids collected at the surface (triangles) and bottom (squares) in the shoaling zone in blue (SZ) and the breaking zone in yellow (BZ) on five days at El Jobo and Rajada beaches. Dates with an asterisk $(*)$ indicate days at which devil rays were observed and/or sampled. scar during our surveys, inspections of photographs taken from the dead individual suggest that at least this individual sampled was indeed a neonate. Size at birth of M. munkiana is yet to be determined but may range from 350 (Notarbartolo di Sciara, 1988) to $423 \mathrm{~mm} \mathrm{~W}_{\mathrm{D}}$ (Broadhurst et al., 2019). Hence, with our smallest individual captures of $490 \mathrm{~mm} \mathrm{WD}$, females may give birth in the vicinity of these bays. Pupping season for M. munkiana in Costa Rica therefore appears similar to reports from Baja California Peninsula, extending from April to June (Palacios et al., 2021). Following local observations and our capture reports, devil rays are not observed within the bays before May nor after September, but a more systematized study is desirable to confirm the boundaries of the reproductive season for Costa Rica.

Mobula munkiana feeds on zooplanktonic crustaceans with main food items varying both spatially and temporally (Coasaca-Céspedes et al., 2018; Notarbartolo di Sciara, 1988). For instance, M. munkiana feeds mainly on mysids that peak during Baja California Peninsula's cold upwelling season (Notarbartolo di Sciara, 1988) and in its absence on the euphausiid Nyctiphanes simplex (Coasaca-Céspedes et al., 2018). Similar to Baja California Peninsula, maximum primary productivity along the north pacific coast of Costa Rica occurs from December to April stimulated by the upwelling Costa Rican Dome (Fiedler, 2002), but zooplankton abundance remains high during most months (Fernández-Álamo \& Färber-Lorda, 2006). In fact, Punta Descartes has the highest zooplankton abundance registered anywhere in the country (Morales-Ramírez et al., 2018), providing suitable habitat for mobulids throughout the year. Although the euphausiid N. simplex is considered a dominant species in upwelling areas of the Eastern Tropical Pacific (Brinton, 1979), coastal zooplankton surveys seem to be dominated by copepods (Morales-Ramírez et al., 2018; Morales-Ramírez et al., 2021), raising questions on the feeding habitats of $M$. munkiana in this area. Our plankton surveys conducted at sites where devil rays exhibited feeding behaviors were exclusively composed 
of mysids, which, together with the stomach content of the dead individual indicates that mysids compose the diet of $M$. munkiana in Costa Rica during at least a portion of its life cycle and at least some months of the year. However, mysids have not been identified in any zooplankton survey published to date, and the general lack of knowledge on Costa Rica's mysid fauna (Price et al., 2009) provides further significance to our finding of mysids at El Jobo and Rajada beach. It also urges for more detailed studies on mysids' interannual dynamic in both shallow and deeper waters.

The benthic association and segregation within shallow depths of mysids are known to occur within and among species (Clutter, 1967), and we observed a significant zonation of mysid abundance within less than 2.5 $\mathrm{m}$ depth, with a gradual increase shoreward. Highest number of individuals were found on the bottom in the breaking zone of the beach, directly where juvenile $M$. munkiana unfurl their cephalic lobes to feed. Thus, the feeding action in depths as shallow as $0.2 \mathrm{~m}$ is probably explained by the higher abundance of prey when compared to deeper waters. In fact, if a similar dynamic of zooplankton species abundance driven by upwelling and post-upwelling events as described for Baja California Peninsula is true for Costa Rica, mysids are less abundant in the only months juvenile devil rays are observed in Punta Descartes. However, the waves' action eventually compensates for their restricted distribution by dispensing them in the water column, making them available for filter feeders capable of entering such shallow waters. The fact that only juveniles of $M$. munkiana were captured furthermore suggests that the presence of this principal diet item, albeit restricted to the breaking zone, might become significant for the initial development of juveniles.

Nonetheless, it is possible that larger, even sexually mature, or reproductive individuals were present in deeper depths of the bays of El Jobo and Rajada. Palacios et al. (2021) found a clear segregation of size classes, where neonates and juveniles were exclusively found in depths of between two and five meters, with adults present in the same bay at depths greater than $5 \mathrm{~m}$. During our surveys, we observed some individuals leaping out of the water at the bays' entrance, but a more rigorous sampling of M. munkiana at different depths should be conducted to further conclude on the different life stages present throughout the year. Surprisingly though was the male to female (M:F) sex ratio of 3:1 we found in Punta Descartes, whereas elasmobranch nursery areas, including Ensenada Grande for M. munkiana (Palacios et al., 2021), are often characterized by a 1:1 sex ratio (Salomón-Aguilar et al., 2009). Sex ratios in adult $M$. munkiana have been reported to differ slightly in different time periods, either in favor of males (López, 2009) or females (Notarbartolo di Sciara, 1988), which in turn is common for adult life stages of many elasmobranchs (Wearmouth \& Sims, 2008). Whether or not our male-skewed sex ratio indicates juvenile segregation or is an artifact of low sample size, this should be investigated in the future. In any case, both El Jobo and Rajada bays are likely providing refuge during vulnerable early-life stages, not only by enhancing growth through prey availability but also by providing protection from predators, such as sharks, which are considerable scarce in the area (Espinoza et al., 2020).

This study is the first to report on a feeding ground for juvenile Munk's devil rays, highlighting the need for local conservation strategies for this vulnerable species. Although the area is yet mostly undeveloped, large-scale development plans focused on resort-like tourism have already been initiated. For instance, a 450-suite hotel, operates directly on the beach and may present potential impacts on the ecological health of the bay, either directly or indirectly. Immediate plans include the construction of similar hotels at Rajada Beach. Because the beaches nor waters of Punta Descartes are included under any protective category of the country's system of conservation areas, such as national parks or reserves, the future of this nursing ground is uncertain and should be highlighted to enforce sustainable 
management plans according to Costa Rica's obligation in the protection of M. munkiana.'

Ethical statement: authors declare that they all agree with this publication and made significant contributions; that there is no conflict of interest of any kind; and that we followed all pertinent ethical and legal procedures and requirements. All financial sources are fully and clearly stated in the acknowledgements section. A signed document has been filed in the journal archives.

See Digital Appendix at: /

Ver Apéndice digital en: revistas.ucr.ac.cr

\section{RESUMEN}

\section{EI diablo se aproxima: comportamiento de alimentación de juveniles de mantas diablo (Mobula munkiana) en aguas poco profundas de Punta Descartes, Costa Rica}

Introducción: La identificación de hábitats críticos para especies vulnerables de elasmobranquios es crucial para tomar medidas de conservación efectivas. La manta diablo o raya de Munk (Mobula munkiana) es endémica del Pacífico Oriental y se sabe poco sobre su biología, ecología y uso de hábitat. Como filtradores, se asume que se concentran en regiones de afloramiento con alta productividad; sus poblaciones se consideran en disminución y requieren información urgente para fundamentar medidas de conservación.

Objetivo: El estudio se realizó para obtener información sobre un comportamiento de alimentación observado en juveniles de M. munkiana, con el fin de proporcionar más información sobre las primeras etapas de vida de esta especie considerada vulnerable a la extinción.

Métodos: De junio a setiembre de 2017 y en agosto de 2018, se observó el comportamiento de alimentación de los juveniles de $M$. munkiana en dos bahías poco profundas de Punta Descartes, en el Pacífico norte de Costa Rica. Los individuos fueron capturados utilizando un método no letal para obtener datos sobre el tamaño, peso y sexo. Se tomaron 100 muestras de plancton en las bahías para inferir la composición de la dieta.

Resultados: Las rayas mostraron un comportamiento de natación repetitivo paralelo a la playa, alimentándose exclusivamente en la zona de rompimiento de las olas en marea baja, a menos de $50 \mathrm{~cm}$ de profundidad. Un total de 12 rayas $M$. munkiana (11 vivas y una encontrada muerta) indicaron una agregación de juveniles para alimentarse. Los anchos de disco variaron de 490 a $610 \mathrm{~mm}$ y el peso entre 1400 a 2300 g. La proporción sexual (machos: hembras) fue de 3:1. En la zona donde rompían las olas se encontró principalmente el orden Mysidaceae.

Conclusiones: El comportamiento específico y la ocurrencia estacional de $M$. munkiana en la zona de estudio parecen estar impulsados por la abundancia de presas. Se necesita más investigación para concluir la presencia de adultos reproductivos a mayor profundidad y sobre el uso de hábitat en los alrededores de Punta Descartes durante todo el año. Esta área se encuentra amenazada por un desarrollo insostenible y requiere estrategias de manejo realistas para garantizar la supervivencia de especies vulnerables y sus hábitats críticos.

Palabras clave: Mobula munkiana; juveniles; rayas diablo; migración; abundancia de presas; comportamiento de alimentación.

\section{REFERENCES}

Alvarado, J. J., Herrera, B., Corrales, L., Asch, J., \& Paaby, P. (2011). Identificación de las prioridades de conservación de la biodiversidad marina y costera en Costa Rica. Revista de Biología Tropical, 59(2), 829-842.

Alves de Mendonça, S., Luz Botêlho Macena, B. C., de Araújo, C. B., Alves Bezerra, N. P., \& Vieira Hazin, F. H. (2020). Dancing with the devil: Courtship behaviour, mating evidences and population structure of the Mobula tarapacana (Myliobatiformes: Mobulidae) in a remote archipelago in the equatorial mid-atlantic ocean. Neotropical Ichthyology, 18(3), 1-14. https://doi.org/10.1590/1982-0224-2020-0008

Ari, C., \& Correia, J. P. (2008). Role of sensory cues on food searching behavior of a captive Manta birostris (Chondrichtyes, Mobulidae). Zoo Biology, 27(4), 294-304. https://doi.org/10.1002/zoo.20189

Braun, C. D., Skomal, G. B., Thorrold, S. R., \& Berumen, M. L. (2015). Movements of the reef manta ray (Manta alfredi) in the Red Sea using satellite and acoustic telemetry. Marine Biology, 162(12), 23512362. https://doi.org/10.1007/s00227-015-2760-3

Brinton, E. (1979). Parameters relating to the distributions of planktonic organisms, especially euphausiids in the eastern tropical Pacific. Progress in oceanography, 8(3), 125-189.

Broadhurst, M. K., Laglbauer, B. J. L., \& Bennett, M. B. (2019). Gestation and size at parturition for Mobula kuhlii cf. eregoodootenkee. Environmental Biology of Fishes, 102(7), 1009-1014. https://doi.org/10.1007/ s10641-019-00886-3

Clutter, R. I. (1967). Zonation of Nearshore Mysids. 48(2), 200-208.

Coasaca-Céspedes, J. J., Segura-Cobeña, E., MonteroTaboada, R., Gonzalez-Pestana, A., Alfaro-Córdova, E., Alfaro-Shigueto, J., \& Mangel, J. C. (2018). 
Preliminary analysis of the feeding habits of batoids from the genera Mobula and Myliobatis in northern Peru. Revista de Biologia Marina y Oceanografia, 53(3), 367-374. https://doi.org/10.22370/ rbmo.2018.53.3.1368

Cortés, J., Samper-Villarreal, J., \& Bernecker, A. (2014). Seasonal phenology of Sargassum liebmannii J. Agardh (Fucales, Heterokontophyta) in an upwelling area of the Eastern Tropical Pacific. Aquatic Botany, 119(OCTOBER), 105-110. https://doi.org/10.1016/j. aquabot.2014.08.009

Couturier, L. I. E., Marshall, A. D., Jaine, F. R. A., Kashiwagi, T., Pierce, S. J., Townsend, K. A., Weeks, S. J., Bennett, M. B., \& Richardson, A. J. (2012). Biology, ecology and conservation of the Mobulidae. Journal of Fish Biology, 80(5), 1075-1119. https:// doi.org/10.1111/j.1095-8649.2012.03264.x

Croll, D. A., Dewar, H., Dulvy, N. K., Fernando, D., Francis, M. P., Galván-Magaña, F., Hall, M., Heinrichs, S., Marshall, A., Mccauley, D., Newton, K. M., Notarbartolo-Di-Sciara, G., O’Malley, M., O'Sullivan, J., Poortvliet, M., Roman, M., Stevens, G., Tershy, B. R., \& White, W. T. (2016). Vulnerabilities and fisheries impacts: the uncertain future of manta and devil rays. Aquatic Conservation: Marine and Freshwater Ecosystems, 26(3), 562-575. https://doi.org/10.1002/ aqc. 2591

Croll, D. A., Newton, K. M., Weng, K., Galván-Magaña, F., O’Sullivan, J., \& Dewar, H. (2012) Movement and habitat use by the spine-tail devil ray in the Eastern Pacific. Ocean Marine Ecology Progress Series, 465,193-200. https://doi.org/10.3354/meps09900

Espinoza, M., Araya-Arce, T., Chaves-Zamora, I., Chinchilla, I., \& Cambra, M. (2020). Monitoring elasmobranch assemblages in a data-poor country from the Eastern Tropical Pacific using baited remote underwater video stations. Scientific Reports, 10(1), 1-18. https://doi.org/10.1038/s41598-020-74282-8

Espinoza, M., Díaz, E., Angulo, A., Hernández, S., \& Clarke, T. M. (2018). Chondrichthyan diversity, conservation status, and management challenges in Costa Rica. Frontiers in Marine Science, 5, 85. https://doi. org/10.3389/fmars.2018.00085

Fernández-Álamo, M. A., \& Färber-Lorda, J. (2006). Zooplankton and the oceanography of the eastern tropical Pacific: A review. Progress in Oceanography, 69(2-4), 318-359. https://doi.org/10.1016/j. pocean.2006.03.003

Fiedler, P. (2002). The annual cycle and biological effects of the Costa Rica Dome. Deep-Sea Research I, 49, 321-338.

Germanov, E. S., \& Marshall, A. D. (2014). Running the Gauntlet: Regional movement patterns of manta alfredi through a complex of parks and fisheries.
PLoS ONE, 9(10). https://doi.org/10.1371/journal. pone. 0110071

Hosegood, J., Humble, E., Ogden, R., de Bruyn, M., Creer, S., Stevens, G. M. W., Abudaya, M., Bassos-Hull, K., Bonfil, R., Fernando, D., Foote, A. D., Hipperson, H., Jabado, R. W., Kaden, J., Moazzam, M., Peel, L. R., Pollett, S., Ponzo, A., Poortvliet, M., ... Carvalho, G. (2020). Phylogenomics and species delimitation for effective conservation of manta and devil rays. Molecular Ecology, 29(24), 4783-4796. https://doi. org/10.1111/mec.15683

Jaine, F. R. A., Couturier, L. I. E., Weeks, S. J., Townsend, K. A., Bennett, M. B., Fiora, K., \& Richardson, A. J. (2012). When Giants Turn Up: Sighting Trends, Environmental Influences and Habitat Use of the Manta Ray Manta alfredi at a Coral Reef. PLoS ONE, 7(10). https://doi.org/10.1371/journal.pone.0046170

Lawson, J. M., Fordham, S. V., O’Malley, M. P., Davidson, L. N., Walls, R. H., Heupel, M. R., Stevens, G., Fernando, D., Budziak, A., Simpfendorfer, C. A., Ender, I., Francis, M. P., Notarbartolo-di-Sciara, G., \& Dulvy, N. K. (2017). Sympathy for the devil: a conservation strategy for devil and manta rays. PeerJ, 5, e3027. https://doi.org/10.7717/peerj.3027

Lezama-Ochoa, N., Hall, M., Román, M., \& Vogel, N. (2019). Spatial and temporal distribution of mobulid ray species in the eastern Pacific Ocean ascertained from observer data from the tropical tuna purse-seine fishery. Environmental Biology of Fishes, 102(1), 1-17. https://doi.org/10.1007/s10641-018-0832-1

Lopez, J. N. S. (2009). Estudio Comparativo de la Reproduccion de tres Especies del Genero Mobula (Chondrichthyes: Mobulidae) en el Suroeaste del Golfo de California, Mexico (Master's thesis). Instituto Politécnico Nacional, La Paz, Baja California Sur, Mexico.

Marshall, A., Barreto, R., Carlson, J., Fernando, D., Fordham, S., Francis, M. P., Herman, K., Jabado, R. W., Liu, K. M., Rigby, C. L., \& Romanov, E. (2019). Mobula munkiana. The IUCN Red List of Threatened Species. https://dx.doi.org/10.2305/ IUCN.UK.2019-3.RLTS.T60198A124450956.en

Morales-Ramírez, Á., Corrales-Ugalde, M., EsquivelGarrote, O., Carrillo-Baltodano, A., Rodríguez-Sáenz, K., \& Sheridan, C. (2018). Marine zooplankton studies in Costa Rica: A review and future perspectives. Revista de Biologia Tropical, 66(Suppl. 1), S24-S41. https://doi.org/10.15517/rbt.v66i1.33258

Morales-Ramírez, Á., Till-Pons, I., Alfaro, E. J., CorralesUgalde, M., \& Sheridan-Rodríguez, C. (2021). Mesozooplankton responses to oceanographic conditions across different scales in Salinas Bay, Northern Pacific coast of Costa Rica during 2011-2013. Revista de Biologia Tropical, 69(Suppl. 2), S142-S159. 
Mulvany, S., \& Motta, P. J. (2013). The morphology of the cephalic lobes and anterior pectoral fins in six species of batoids. Journal of Morphology, 274(9), 1070-1083. https://doi.org/10.1002/jmor.20163

Notarbartolo di Sciara, G. (1987). A revisionary study of the genus Mobula Rafinesque, 1810 (Chondrichthyes: Mobulidae) with the description of a new species. Zoological Journal of the Linnean Society, 91(1), 1-91. https://doi.org/10.1111/j.1096-3642.1987. tb01723.x

Notarbartolo di Sciara, G. (1988). Natural history of the rays of the genus Mobula in the Gulf of California. Fishery Bulletin, 86(1), 45-66.

Notarbartolo di Sciara, G., Adnet, S., Bennett, M., Broadhurst, M. K., Fernando, D., Jabado, R. W., Laglbauer, B. J. L., \& Stevens, G. (2020). Taxonomic status, biological notes, and conservation of the longhorned pygmy devil ray Mobula eregoodoo (Cantor, 1849). Aquatic Conservation: Marine and Freshwater Ecosystems, 30(1), 104-122. https://doi. org/10.1002/aqc.3230

Notarbartolo di Sciara, G., Fernando, D., Adnet, S., Cappetta, H., \& Jabado, R. W. (2017). Devil rays (Chondrichthyes: Mobula) of the Arabian Seas, with a redescription of Mobula kuhlii (Valenciennes in Müller and Henle, 1841). Aquatic Conservation: Marine and Freshwater Ecosystems, 27(1), 197-218. https://doi.org/10.1002/aqc.2635

O’Malley, M. P., Townsend, K. A., Hilton, P., Heinrichs, S., \& Stewart, J. D. (2017). Characterization of the trade in manta and devil ray gill plates in China and South-east Asia through trader surveys. Aquatic Conservation: Marine and Freshwater Ecosystems, 27(2), 394-413. https://doi.org/10.1002/aqc.2670

Palacios, M. D., Hoyos-Padilla, E. M., Trejo-Ramírez, A., Croll, D. A., Galván-Magaña, F., Zilliacus, K. M., O’Sullivan, J. B., Ketchum, J. T., \& González-Armas, R. (2021). Description of first nursery area for a pygmy devil ray species (Mobula munkiana) in the Gulf of California, Mexico. Scientific Reports, 11(1), 1-11. https://doi.org/10.1038/s41598-020-80506-8

Price, W., Heard, R., \& Vargas, R. (2009). Shallow Water Mysids. In I. Wehrtmann \& J. Cortés (Eds.), Marine Biodiversity of Costa Rica, Central America (pp. 229-236). Springer, Dordrecht. https://doi. org/10.1007/978-1-4020-8278-8_20

R Core Team (2020). R: A language and environment for statistical computing. R Foundation for Statistical Computing, Vienna, Austria.
Rohner, C. A., Pierce, S. J., Marshall, A. D., Weeks, S. J. Bennett, M. B., \& Richardson, A. J. (2013). Trends in sightings and environmental influences on a coastal aggregation of manta rays and whale sharks. Marine Ecology Progress Series, 482, 153-168. https://doi. org/10.3354/meps 10290

Salomón-Aguilar, C. A., Villavicencio-Garayzar, C. J., \& Reyes-Bonilla, H. (2009). Zonas y temporadas de reproducción y crianza de tiburones en el Golfo de California: Estrategia para su conservación y manejo pesquero. Ciencias Marinas, 35(4), 369-388. https:// doi.org/10.7773/cm.v35i4.1435

Sampson, L., Galván-Magaña, F., de Silva-Dávila, R., Aguíñiga-García, S., \& Ósullivan, J. B. (2010). Diet and trophic position of the devil rays Mobula thurstoni and Mobula japanica as inferred from stable isotope analysis. Journal of the Marine Biological Association of the United Kingdom, 90(5), 969-976. https://doi.org/10.1017/S0025315410000548

Stewart, J. D., Jaine, F. R. A., Armstrong, A. J., Armstrong, A. O., Bennett, M. B., Burgess, K. B., Couturier, L. I. E., Croll, D. A., Cronin, M. R., Deakos, M. H., Dudgeon, C. L., Fernando, D., Froman, N., Germanov, E. S., Hall, M. A., Hinojosa-Alvarez, S., Hosegood, J. E., Kashiwagi, T., Laglbauer, B. J. L., ... Stevens, G. M. W. (2018). Research priorities to support effective Manta and Devil Ray conservation. Frontiers in Marine Science, 5, 314. https://doi.org/10.3389/ fmars.2018.00314

Stewart, J. D., Rohner, C. A., Araujo, G., Avila, J., Fernando, D., Forsberg, K., Ponzo, A., Rambahiniarison, J. M., Kurle, C. M., \& Semmens, B. X. (2017). Trophic overlap in mobulid rays: Insights from stable isotope analysis. Marine Ecology Progress Series, 580, 131-151. https://doi.org/10.3354/meps12304

Wearmouth, V. J., \& Sims, D. W. (2008). Chapter 2. Sexual Segregation in Marine Fish, Reptiles, Birds and Mammals. Behaviour Patterns, Mechanisms and Conservation Implications. Advances in Marine Biology, 54(08), 107-170. https://doi.org/10.1016/ S0065-2881(08)00002-3

White, W. T., Corrigan, S., Yang, L., Henderson, A. C., Bazinet, A. L., Swofford, D. L., \& Naylor, G. J. P. (2018). Phylogeny of the manta and devilrays (Chondrichthyes: Mobulidae), with an updated taxonomic arrangement for the family. Zoological Journal of the Linnean Society, 182(1), 50-75. https://doi. org/10.1093/zoolinnean/zlx018 